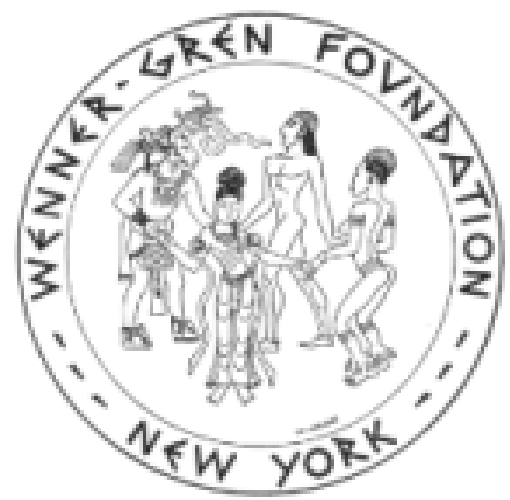

Mobile Pastoralists in the Logone Floodplain Distribute Themselves in an Ideal Free Distribution

Author(s): Mark Moritz, Ian M. Hamilton, Yu-Jen Chen, and Paul Scholte

Source: Current Anthropology, Vol. 55, No. 1 (February 2014), pp. 115-122

Published by: The University of Chicago Press on behalf of Wenner-Gren Foundation for

Anthropological Research

Stable URL: http://www.jstor.org/stable/10.1086/674717

Accessed: 25/01/2014 08:42

Your use of the JSTOR archive indicates your acceptance of the Terms \& Conditions of Use, available at http://www.jstor.org/page/info/about/policies/terms.jsp

JSTOR is a not-for-profit service that helps scholars, researchers, and students discover, use, and build upon a wide range of content in a trusted digital archive. We use information technology and tools to increase productivity and facilitate new forms of scholarship. For more information about JSTOR, please contact support@jstor.org.

The University of Chicago Press and Wenner-Gren Foundation for Anthropological Research are collaborating with JSTOR to digitize, preserve and extend access to Current Anthropology. 


\section{Mobile Pastoralists in the Logone Floodplain Distribute Themselves in an Ideal Free Distribution}

\section{Mark Moritz, Ian M. Hamilton, Yu-Jen Chen, and Paul Scholte}

Department of Anthropology, The Ohio State University, 174 West 18th Avenue, Columbus, Ohio 43210-1106, U.S.A. (mark.moritz@gmail.com)/Department of Evolution, Ecology, and Organismal Biology, Department of Mathematics, The Ohio State University, 390 Aronoff Laboratory, 318 West 12th Avenue, Columbus, Ohio 43210, U.S.A./Department of City and Regional Planning, The Ohio State University, 275 West Woodruff Avenue, Columbus, Ohio 43210, U.S.A./c/o Nieuwe Teertuinen 12C, Amsterdam, LV 1013, the Netherlands. This paper was submitted 7 IX 12, accepted 22 VII 13, and electronically published 18 XII 13.

\section{CA+ Online-Only Material: Supplement A}

We examined whether mobile pastoralists in the Logone floodplain of Cameroon distribute themselves according to the ideal free distribution (IFD), which predicts that the number of individuals in each area is proportional to the quality and quantity of resources in each area and that all individuals have access to the same amount of resources. We used the concept to assess the distribution of grazing pressure over available common-pool resources as evidence of a complex adaptive system in which the spatial distribution grazing pressure is adjusted to the distribution of resources through individual decision making and passive coordination of movements among individual pastoralists. We used a combination of spatial and ethnographic approaches to study the distribution of resources and mobile pastoralists in the Logone floodplain in 5 successive years and found evidence for an IFD in 3 years (2008-2009 and 2012) and an approximation of an IFD in years in which pastoralists were terrorized by armed bandits (2010) and the government reestablished security (2011). The findings support our hypothesis that there is a self-organizing management system in which pastoralists distribute themselves effectively over the available resources.

In this article we examine pastoral management of commonpool grazing resources in a complex social-ecological system. Specifically, we examine whether mobile pastoralists in the Logone floodplain in the Far North Region of Cameroon distribute themselves according to the theory of the ideal free distribution (IFD; Fretwell and Lucas 1969), which predicts that individuals will settle first in habitats with high-resource density and that, at any given time, all individuals have access

(C) 2014 by The Wenner-Gren Foundation for Anthropological Research. All rights reserved. 0011-3204/2014/5501-0006\$10.00. DOI: $10.1086 /$ 674717 to the same amount of resources. In assessing the distribution of grazing pressure over available common-pool resources, we use the ideal free distribution as an indicator of management of these resources in a situation in which pastoralists are committed to an ethos of open access to common-pool grazing resources (Moritz et al. 2013).

Pastoralists' use of common-pool grazing resources in the Logone floodplain is best described as open access as there are no institutions that regulate pastoral use of and access to the floodplain (Moritz et al. 2013). On the contrary, pastoralists emphatically argue that access is open for everyone, and every year, after the water recedes, thousands of Arab and FulBe pastoralists from Cameroon, Nigeria, and Niger move with more than 200,000 cattle into the Logone floodplain (Seignobos and Iyébi-Mandjek 2000; Zborowski 1996).

Open access to common-pool resources has been equated with the tragedy of the commons (Hardin 1968). However, critics have argued that Hardin confused commons with open access or unmanaged common-pool resources (Ciriacy-Wantrup and Bishop 1975; McCay and Acheson 1987; Ostrom 1990). Moreover, Ostrom (1990) has shown that common-pool resources can be managed sustainably as common property regimes using game-theoretical models and a wide range of empirical cases of successful commons. The current consensus in the literature on pastoral systems is that in most cases commonpool resources are managed as common property regimes but also that open access will lead to a tragedy of the commons (Galvin 2009; Homewood 2008).

Here we will present evidence in support of our hypothesis that the management system in the Logone floodplain is a self-organizing complex adaptive system (Moritz et al. 2013). As evidence for management of common-pool resources we expect to see that the distribution of grazing pressure is proportional to the distribution of resources within the floodplain as in an ideal free distribution.

\section{The Ideal Free Distribution Model}

The ideal free distribution is a simple and elegant game theoretic model that lies at the basis of many other behavioral ecology models that explain the relationship between animal behavior and population dynamics (Fretwell and Lucas 1969; Sutherland 1996). The IFD model predicts how animals should distribute themselves over resource habitats or patches. The two main assumptions in the IFD model that give it its name are (1) individuals have complete knowledge about the resource quality and quantity of each patch (ideal assumption) and (2) individuals are free to move to any patch (free assumption). When those conditions are met, the theory predicts that individuals should be distributed such that no individual can gain more resources by moving to a different patch. However, empirical studies of fish and birds have not always found support for the model (Sutherland 1996).

There are many different versions of the IFD model, but 
the depletion model is the most appropriate IFD model to examine the pastoral use of forage in the Logone floodplain (Hamilton 2010b; Sutherland and Anderson 1993). There are several predictions that arise from this model. First is that occupied habitats have higher resource density than do unoccupied habitats at any point in time, because high-resource habitats are occupied first. Second, the variance in standing resource quality of occupied habitats should be lower than the variance in resource quality of unoccupied habitats, because foragers will tend to deplete all occupied habitats to the same quality while, in unoccupied habitats, current resource quality is unaffected by depletion. Finally, there should be a positive correlation between total resources in a habitat (resource density $\times$ area) and total number of foragers in a habitat. Under a model incorporating only depletion, resource quality per unit area should be equal in all occupied habitats; however, if habitats vary in area, larger habitats should include more individuals (Flaxman and deRoos 2006; Fretwell and Lucas 1969).

The concept of the IFD has been primarily used in behavioral ecology studies to examine habitat selection and foraging strategies of animals (Hamilton 2010a; Kennedy and Gray 1993; Sutherland 1996), but it is now also used to study the mobility and settlement patterns of human populations (Kennett, Anderson, and Winterhalder 2006; Winterhalder et al. 2010), including mobile pastoralists (Behnke, Davidson et al. 2008; Behnke, Fernandez-Gimenez et al. 2011; Scholte et al. 2006). Pastoral systems provide an excellent case for examining IFD theory because the mobility and settlement patterns of pastoralists are primarily driven by spatiotemporal changes in the distribution of forage and water, even though the human dimension of pastoral systems means that nonforage constraints shape mobility and settlement patterns (Behnke, Fernandez-Gimenez et al. 2011).

Theoretical and formal models are necessarily much simpler than the complexity of social-ecological systems, and this is why the concept of the IFD is often used as a heuristic device (Kennett, Anderson, and Winterhalder 2006). However, in many ways the social-ecological system of the Logone floodplain is an appropriate setting to use the concept of the IFD to describe and evaluate the distribution of mobile pastoralists. Most importantly, the system meets the IFD's two main assumptions: first, while pastoralists do not have perfect information, they have reliable information about the suitability of different habitats through a combination of scouting and social networks; second, access to common-pool grazing resources in the floodplain is best described as open access in that there are no regulations restricting access, which means that pastoralists are free to relocate if it is to their advantage to do so. We argue that the IFD, and, in particular, the depletion model, is a useful concept to understand the distribution of pastoralists in the Logone floodplain. The socialecological system, however, does not fit several of the other assumptions of ideal free models (see supplement A, available online, for a detailed discussion).
Ideal free models do not necessarily alleviate the tragedy of the commons. Indeed, in depletion models, depletion may become severe over the whole landscape, as even very poor habitats become occupied (Sutherland 1996). However, we argue that (1) because pastoralists live in an open system in which they can move within and out of the floodplain, the number of available habitats becomes very large at large spatial scales and (2) in the spatiotemporal patterns of resource depletion and renewal, in which depleted habitats are renewed and the spatial distribution of herders on the floodplain is reset by the onset of the rainy season and flooding, full occupancy and severe depletion of all habitats in the limited time of the dry season is unlikely. In other words, we expect that over a wide range of conditions, individuals can do better by moving rather than by increasing intensity of exploitation in a given habitat. We thus expect to find an ideal, free-type distribution when mobile users with complete information, freedom and ability to move, independent and individual decision-making capabilities, and a preference for habitual campsites have open access to depletable common-pool resources that are highly variable in space and time. Such a distribution will be resistant to strategies that overselect or overstay in certain habitats, because the costs of overusing these habitats fall most heavily on the individuals that overuse them (Hamilton 2010a).

\section{Study Area and Population}

Two phytogeographic zones characterize the Far North Region of Cameroon: Sudanian in the southern grades and Sahelian in the Logone floodplain. The Logone floodplain is flooded by the Logone River and its branches from September until November. After the water recedes in December, thousands of Arab and FulBe pastoralists from Cameroon, Nigeria, and Niger move with more than 200,000 cattle into the floodplain, making it one of the most important dry season grazing lands in the Lake Chad Basin (Seignobos and Iyébi-Mandjek 2000). Many remain there until the start of the rainy season in June, while others move to other seasonal grazing areas. Pastoralists find nutritious regrowth and surface water in the floodplain far into the dry season, when surrounding pastures have dried up. At the start of the rainy season, pastoralists return to Diamaré plains or their respective countries.

The vegetation in the floodplain is relatively homogeneous in terms of forage quantity and quality because of the extreme flatness of the area resulting in only limited variation in flooding depth and duration (Scholte 2007). There is only weak coupling between herbivores and vegetation, as the predominantly perennial vegetation is controlled by flooding depth and duration and naturally protected against overgrazing because up to two-thirds of the biomass is stored underground. In addition, above-ground biomass is generally inaccessible to livestock during the flooding for 6 months of the year (Scholte 2007).

Our study area, called Yaayre in Fulfulde, is an approxi- 


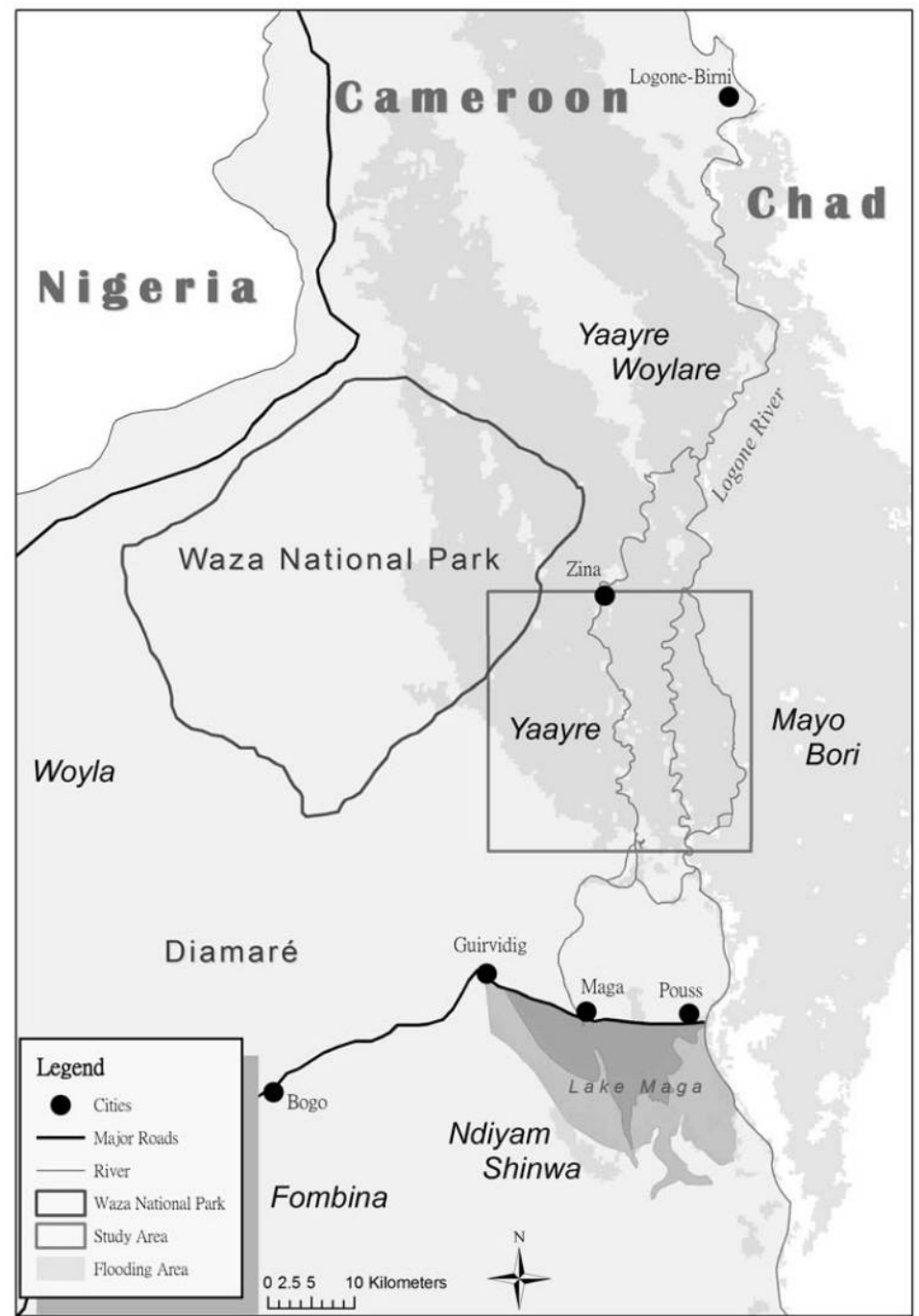

Figure 1. The study area in the Far North Region of Cameroon.

mately $800 \mathrm{~km}^{2}$ section of the Logone floodplain with welldefined boundaries of the Waza National Park in the west, the Logone River in the east, the irrigated rice fields of SEMRY in the south, and the village of Zina in the north (see fig. 1). The research site overlaps with the pilot zone of the Waza Logone Project (1990-2003), which started reflooding of the pilot zone by opening an old waterway in the embankment along the Logone River in 1994 (Loth 2004; Scholte 2005; Scholte et al. 2006).

The study population consists of all mobile pastoralists who use the Logone floodplain at some point during the year. Many of them use the floodplain during the cold dry season in November and December when the water retreats and then either leave for the floodplain further north (Yaayre Woylare) or the lakeshore pastures of Lake Maga in the south (Ndiyam
Shinwa). The population consists of approximately 1,000 households divided over approximately 130 camps and includes Suwa Arabs and FulBe, which are subdivided in Jamaare, Mare, Alijam, Adanko, and Anagamba groups. These different FulBe groups are endogamous and have their own dialect, cattle breed, houses, and marriage system.

Pastoralists set up their camps in koodaande (singular hoodaande), which refer to sites, that is, the location of herds and households, as well as the larger area in which these sites are located. We refer to the former as campsites and the latter as camp zones. In the floodplain, camp zones are often located in depressions for easy access to water for humans and calves and protection from bush fires. They are also located close to the three rivers that intersect the floodplain in the east or close to the artificial lakes in the west that were dug by the 
Table 1. Results from unpaired $t$-test comparing NDVI values of occupied and unoccupied cells in February, 2008-2012

\begin{tabular}{|c|c|c|c|c|c|c|c|c|c|c|c|}
\hline \multirow[b]{2}{*}{ Year } & \multicolumn{4}{|c|}{ Occupied cells } & \multicolumn{4}{|c|}{ Unoccupied cells } & \multicolumn{3}{|c|}{ Unpaired $t$-test } \\
\hline & Avg. & Min & $\operatorname{Max}$ & Variance & Avg. & Min & $\operatorname{Max}$ & Variance & $t$ & df & $P$ - values \\
\hline 2008 & .244 & .156 & .306 & .0008 & .242 & .130 & .362 & .0017 & .662 & 787 & .6620 \\
\hline 2009 & .261 & .165 & .362 & .0008 & .251 & .157 & .381 & .0015 & 3.924 & 787 & $<.0001^{\star}$ \\
\hline 2010 & .255 & .188 & .326 & .0008 & .242 & .182 & .378 & .0010 & 5.363 & 787 & $<.0001^{\star}$ \\
\hline 2011 & .296 & .239 & .363 & .0005 & .293 & .191 & .412 & .0013 & 1.351 & 787 & .1772 \\
\hline 2012 & .267 & .196 & .334 & .0006 & .246 & .166 & .335 & .0008 & 1.294 & 787 & $<.0001^{\star}$ \\
\hline
\end{tabular}

Note. The average normalized difference vegetation index (NDVI) values in occupied cells are significantly higher in 3 of the 5 years. Moreover, the variance is much greater in the unoccupied cells compared to the occupied cells.

* Significant at the $1 \%$ level.

Lake Chad Basin Commission (LCBC). Some camp zones are places where pastoralists stay for an extended period (sojourn), up to 6 months, while in other zones they stay for only a few days (transit). Different pastoralists may use the same camp zones for either transit or sojourn.

In general, mobile pastoralists in our sample had three sojourn camps each year: in the rainy season (duumol), cold dry season (daBBunde), and the hot dry season (ceedu). These campsites are referred to, respectively, as ruumirde, daBBirde, and ceedirde. Pastoralists generally stayed the longest in their ceedirde, some up to 6 months. By February pastoralists have settled in their ceedirde in the Yaayre, while the ones that have their ceedirde in Ndiyam Shinwa and Yaayre Woylare have left. In the hot dry season, access to water restricts, and pastoralists settle in a limited number of well-established camp zones near the rivers that dissect the floodplain or near the artificial lakes in the western end of the floodplain. They generally stay there until the beginning of the rainy season (in June) or whenever they think that their animals will do better elsewhere.

\section{Methods}

Data for this article were collected in a longitudinal study of pastoral mobility in the Far North Region of Cameroon (2008-2012). We used a combination of spatial and ethnographic approaches to describe and explain the distribution of mobile pastoralists in our study area in the Logone floodplain in 5 successive years, 2008-2012.

To document the distribution of mobile pastoralists, we used GPS/GIS technology to map the locations of all pastoralists' camps in our study area in the floodplain at three different times during the year (November, February, May). During these visits, we identified all the households in the camp, the number of herds, and the name of the campsite.

To estimate the distribution of the available resources in the floodplain we used remote sensing data, in particular the normalized difference vegetation index (NDVI), which is an indicator of the quality and quantity of forage. NDVI is one of the most common remote sensed vegetation indices for measuring the plant growth and vegetation cover (Anyamba and Tucker 2005), including in the assessment of pastoral ecosystems (Butt 2010; Coughenour et al. 2008). We used
MODIS MOD13A2 satellite data, which are collected every 16 days at $1 \mathrm{~km}$ resolution, to calculate the NDVI values for our study area. While NDVI is not a reliable index for absolute measurements of vegetation, it is very useful as a relative measure of green biomass in the same area at the same time (Anyamba and Tucker 2005).

Using ArcGIS software, we divided up our study areas in a grid with $1 \mathrm{~km}^{2}$ cells and calculated the NDVI value for all $1 \mathrm{~km}^{2}$ cells in the study areas for the month of February. We used pastoralists' camp zones as our habitats. To calculate the NDVI for the camp zones we created buffers with a $1.5 \mathrm{~km}$ radius around each campsite (using the GPS coordinates from our surveys). We combined the buffers that overlapped and shared toponyms into one larger buffer (e.g., all the buffers from the Cubuna campsites were combined into one Cubuna buffer).

We used a combination of statistical analyses to examine whether there was an IFD of mobile pastoralists in the Logone floodplain (using GraphPad InStat [version 3.0a] and SPSS [version 19] for Macintosh). First, we used descriptive statistics, $t$-tests, and analysis of variance (ANOVA) to describe and compare the NDVI values for the study area, as well as the occupied and unoccupied cells in the different years. Second, we used descriptive statistics to describe the population of mobile pastoralists for the different years (2008-2012). Third, we used correlations and multiple regressions to examine whether there is a correlation between the NDVI and the number of cattle for the camp zones in each year. We also calculated for each camp zone the percentage of the NDVI and of cattle (as a percentage of all the camp zones combined for each year) to examine whether there was under use or overuse of habitats and whether there was a correlation between the properties of each camp zone (e.g., NDVI, number of cattle) and under use or overuse.

\section{Results}

Here we will describe the results from our study. First, we describe patterns in NDVI and the pastoral population. Second, we will discuss correlations between the NDVI and grazing pressure for 5 years (2008-2012). 
Table 2. Population of mobile pastoralists in the study area in February, 2008-2012

\begin{tabular}{lcccccc}
\hline & No. camps & No. cattle & No. households & Households per camp & Cattle per household & Cattle per camp \\
\hline 2008 & 36 & 26,370 & 296 & 8.2 & 89 & 83 \\
2009 & 55 & 36,985 & 445 & 383 & 672 \\
2010 & 57 & 34,270 & 318 & 6.7 & 69 \\
2011 & 54 & 30,410 & 271 & 4.7 & 56 \\
2012 & 58 & 21,750 & 343 & 6.8 & 80 \\
Average & 52 & 29,957 & 574 & 87 \\
\hline
\end{tabular}

Note. The number of cattle per herd are estimated and based on self-reporting, vaccination records, and direct counts as assessed during our earlier studies (Scholte et al. 2006).

\section{NDVI in Camp Zones}

The Logone floodplain is extremely flat, and the vegetation is relatively homogeneous, and initially we envisioned the floodplain as one large camp zone. However, analysis of transhumance surveys and GPS data of their camps shows that there are distinct camp zones that are occupied year after year, while other areas are never occupied.

A visual inspection shows that most of the camp zones are located near depressions and water sources (e.g., rivers and the artificial lakes). We also examined whether cells in the camp zones have more grazing resources by comparing the NDVI values inside the camp zone buffers (occupied cells) and outside the buffers (unoccupied cells) for 5 different years (2008-2012). We found a number of differences in NDVI between occupied and unoccupied areas, which all support our predictions. First, the average NDVI values are higher for occupied areas in all 5 years, and in 3 years the differences are statistically significant (see table 1). Second, the distribution of NDVI in the occupied cells passed the normality test using the Kolmogorov-Smirnov test $(P>.10)$, but the unoccupied cells did not $(P<.007)$. Third, the range of NDVI values is much larger and the variance is higher in unoccupied cells than in occupied cells in all 5 years (see table 1). Moreover, if we compare the average NDVI values for the different camp zones (total NDVI/ surface area), which is an indicator of resource quality per unit area, we found very little variance between camp zones (see supplement A for more information on intra- and interannual changes in NDVI).

Table 3. Correlations between NDVI and number of animals in camp zones, 20082012

\begin{tabular}{lccc}
\hline & \multicolumn{3}{c}{ Linear correlation } \\
\cline { 2 - 4 } Year & $r$ & $N$ & $P$ \\
\hline 2008 & .8270 & 16 & $<.0001^{\star}$ \\
2009 & .7431 & 17 & $.0006^{*}$ \\
2010 & .4394 & 17 & .0776 \\
2011 & .4648 & 18 & .0520 \\
2012 & .8558 & 16 & $<.0001^{*}$ \\
\hline
\end{tabular}

Note. In all 5 years there are strong correlations between the total normalized difference vegetation index (NDVI) and the number of animals in camp zones.

* Significant at the $1 \%$ level.

\section{Changes in Pastoral Population in the Study Area}

The pastoral population in the Logone floodplain in February changed from year to year, and this is an indication of how decision making of individual pastoralists results in adjustment of grazing pressure at the regional level. The pastoral population in the floodplain in February represents about a third of the mobile pastoralists in our study population (Moritz et al. 2013). In February, at the beginning of the hot dry season, another third has moved further north to the floodplain called Yaayre Woylare, while the remainder has moved south to the grazing areas surrounding Lake Maga or the floodplain in neighboring Chad.

The number of camps in our study area in February ranged from 36 in 2008 to 58 in 2012 with an average of 52 for all 5 years (see table 2). The number of households also varied considerably from year to year, with 271 in 2012 and 445 in 2009_an average of 343 for all 5 years. The same is true for the number of cattle, which varied from 21,750 in 2012 and 36,985 in 2009—an average of 29,957 for all 5 years.

Moreover, there are no statistically significant correlations between the number of camps and the households; these numbers vary independently of each other. It is an indication of the flexibility of the social system, which is the result of continuous processes of fission and fusion in the social organization of camps. Every time pastoralists move, the composition of the camp potentially changes. Households from one camp can decide to split ways, or households from different camps can decide to set up camp together (or both). Households are autonomous decision-making units, and pastoralists make independent decisions about where and when to move. This indicates that there is considerable flexibility in the system and that there are no major social constraints in the movements of pastoralists (see supplement A for more information on change and continuity in pastoral populations).

\section{Matching NDVI and Animal Numbers}

We further examined whether there was evidence for an ideal free distribution in the Logone floodplain by testing whether there was a positive correlation between the total NDVI and the total number of animals per camp zone for the 5 different years. We found strong correlations between the NDVI and number of animals per camp zone buffer in 3 of the years 
Table 4. Correlations between overuse and under use and number of animals in camp zones, 2008-2012

\begin{tabular}{ccccccc}
\hline & \multicolumn{3}{c}{ Linear correlation } & & \multicolumn{2}{c}{ Matching in zones } \\
\cline { 2 - 3 } Year & $r$ & $N$ & & & Over & Under \\
\hline 2008 & .8423 & 16 & $<.0001^{*}$ & & 6 & 10 \\
2009 & .6705 & 17 & $.0032^{*}$ & & 5 & 12 \\
2010 & .8758 & 17 & $<.0001^{*}$ & & 6 & 11 \\
2011 & .7461 & 18 & $.0004^{*}$ & & 6 & 12 \\
2012 & .9174 & 16 & $<.0001^{*}$ & 6 & 10 \\
\hline
\end{tabular}

Note. There are strong correlations between the degree of overuse and under use and the number of animals in camp zones. Camp zones with higher numbers of animals are more likely to be overused.

* Significant at the $1 \%$ level.

$(2008,2009,2012)$ and near significant correlations in the other 2 years $(2010,2011$; see table 3$)$. The fact that the correlation is positive in all 5 years suggests that there is a consistent pattern between NDVI and the number of animals across camp zones. Moreover, if we remove the outlier camp zone Lugge with 5,560 animals in 2010, there is a statistically significant correlation $(r=0.6704, n=16, P=.0045)$.

We also examined whether there were any patterns in overuse and under use, that is, whether the percentage of NDVI per camp zone buffer (as a percentage of the NDVI of all the camp zone buffers) was equal to the percentage of animals per camp zone buffer (as a percentage of the animals in all the camp zone buffers) in each of the years. If the percentage of animals was higher than the percentage of NDVI, it is considered a case of overuse (more animals than resources). If the percentage of animals was lower than the percentage of NDVI, it is considered under use (fewer animals than resources). We found that the number of camp zones that were overused stayed more or less the same across the years (see table 4). Although it was not always the same camp zones that were overused (see supplement A for maps of the distribution of pastoralists in relation to NDVI), the camp zones that were used every year (or more frequently) were more likely to be overused than the zones that were not used every year (Spearman $r=0.7030, n=32, P<.0001$ ). In addition, the camp zones with more animals were more likely to be overused than the camps with fewer animals (see table 4). This is not surprising, because the difference between NDVI values in camp zone buffers vary relatively little (see table 1), while the number of animals per camp zone varies considerably (see table 5).

Table 5. Number of animals per camp zone, 2008-2012

\begin{tabular}{cccccc}
\hline Year & Average & SD & Min & Max & Total for study area \\
\hline 2008 & 1,648 & 1,066 & 255 & 3,810 & 26,370 \\
2009 & 2,175 & 1,458 & 390 & 5,735 & 36,985 \\
2010 & 2,016 & 1,354 & 425 & 5,560 & 34,270 \\
2011 & 1,689 & 1,142 & 255 & 4,145 & 30,410 \\
2012 & 1,357 & 1,180 & 210 & 3,950 & 21,715 \\
\hline
\end{tabular}

\section{Interference Due to Insecurity}

While we found strong support for our predictions of the distribution of mobile pastoralists in the Logone floodplain in 2008-2009 and 2012, the evidence is less strong in 2010 2011. One explanation for the absence of strong evidence for an IFD in these years may be the insecurity in the Far North Region during those years. Mobile pastoralists were terrorized by armed bandits (called coupeurs de route), who kidnapped children for ransom (Moritz and Scholte 2011). The kidnappings started in the rainy season of 2009 and continued for more than a year. In October 2009, when pastoralists moved from their rainy season camp zones to the Logone floodplain, six children were taken hostage, and 31 million francs (approximately $\$ 61,600$ ) was paid in ransoms (OPEN 2009). The bandits were well organized and heavily armed, and they did not hesitate to kill. They operated in small groups of three to five, and are thought to be mostly former rebels, army deserters, and outcasts from pastoral groups in the Chad Basin. Livestock traders and pastoralists were their main targets, and they operated in the bush and on secondary roads linking the weekly rural markets (Moritz and Scholte 2011). As a result, many pastoralists changed their annual transhumance orbit and stayed away from their habitual camp zones if they considered the risks of kidnappings too high. Instead, they opted for staying closer to others to minimize the risks of attacks. Many pastoralists in those years talked about leaving Cameroon altogether and leaving for Nigeria or Chad (and a few did).

While we have collected qualitative and quantitative data on insecurity in the Far North Region (Moritz and Scholte 2011), there is no clear evidence for the impact of insecurity in our study area in terms of the number of animals and the distribution of the camps, which do not seem to be different from other years. However, the composition of the pastoral population changed; pastoralists that previously stayed further north in Yaayre Woylare during the hot dry season now stayed in our study area. What is different is the weak correlation between NDVI and the number of animals during the years of insecurity in the Far North Region, suggesting that insecurity had an impact on how pastoralists distributed themselves over the available grazing resources.

\section{Discussion}

We derived three predictions from the depletion and interference models of the IFD. First, occupied areas should have higher resource density than do unoccupied areas at any point in time. Second, the variance in resource quality of occupied areas should be lower than the variance in resource quality of unoccupied areas. Third, there should be a positive correlation between total resources and total animal numbers in a camp zone buffer. Our findings lend support for all three predictions. First, the resource density in occupied areas is significantly higher in 3 of the 5 years. Moreover, we find that areas that are occupied year after year have significantly more 
resources. Second, in all 5 years we find that there is lower variance in resources in occupied areas than in unoccupied areas. Third, we find a positive correlation between the total resources and total numbers of cattle in a camp zone buffer in all 5 years. The results do not allow us to make inferences about which exact combination of formal depletion and in terference models best describes the distribution of mobile pastoralists in the Logone floodplain, but there is clearly support for an ideal, free-type distribution.

Using behavioral ecology models like the IFD to study the dynamics of complex social-ecological systems comes with its own set of challenges. First, social-ecological systems likely do not meet all the assumptions underlying the models (see supplement A for a detailed discussion). Second, human be havior is more complex than habitat selection or forage strategies in the models, which is, of course, true for all theoretica' models. However, the advantage of using models, like the IFD, to study complex social-ecological systems lies in its simplicity. In this case, for example, it helps us to understand the spatiotemporal complexity of pastoral mobility. Pastoral mobility in arid and semiarid lands can be explained at the macro level in terms of spatiotemporal patterns in availability in forage and water, which in turn is driven by seasonal pat. terns in rainfall (see also McCabe 2004). The question that remains, however, is how exactly the IFD emerges. We think that it emerges from a dynamic process in which open access, habitual movements, participation in an information-sharing network, and pastoralists' independent decision making are all critical factors (Moritz et al. 2013) and plan to examine that hypothesis using an agent-based model.

\section{Acknowledgments}

We would like to thank the mobile pastoralists in the Far North Region of Cameroon for participating in this study We also want to thank Centre d'Appui a la Recherche et au Pastoralisme (CARPA) for research support in the field. Thi research has been supported by the National Science Foundation (BCS-0748594), the National Geographic Society (8306-07), and the College of Social and Behavioral Sciences and the Department of Anthropology at Ohio State University (OSU). We would like to thank the Ministry of Scientific Research and Innovation (MINRESI), the Wildlife College in Garoua, and the Higher Institute of the Sahel at the University of Maroua for granting research permission and research affiliation (2008-2012). Yu-Jen Chen made the figures and maps. We would like to thank the reviewers for their critical comments and helpful suggestions.

\section{References Cited}

$\rightarrow$ Anyamba, A., and C. J. Tucker. 2005. Analysis of Sahelian vegetation dynamics using NOAA-AVHRR NDVI data from 1981-2003. Journal of Arid Envi ronments 63:596-614.

Behnke, R., G. Davidson, A. Jabbar, and M. Coughenour. 2008. Human and natural factors that influence livestock distribution and rangeland desertification in Turkmenistan. In NATO Science for Peace and Security Series. R. Behnke, ed. Pp. 141-170. Dordrecht: Springer.

Behnke, R. H., M. E. Fernandez-Gimenez, M. D. Turner, and F. Stammler. 2011. Pastoral migration: mobile systems of livestock husbandry. In Animal migration: a synthesis. E. J. Milner-Gulland, J. M. Fryxell, and A. R. E. Sinclair, eds. Pp. 144-171. Oxford: Oxford University Press.

Butt, B. 2010. Pastoral resource access and utilization: quantifying the spatial and temporal relationships between livestock mobility, density and biomass availability in southern Kenya. Land Degradation and Development 21(6): 520-539.

Ciriacy-Wantrup, S. V., and R. C. Bishop. 1975. "Common property" as a concept in natural resources policy. Natural Resources Journal 15:713-727. Coughenour, M., R. Behnke, J. Lomas, and K. Price. 2008. Forage distributions, range condition, and the importance of pastoral movement in Central Asia- a remote sensing study. In NATO Science for Peace and Security Series. R. Behnke, ed. Pp. 45-80. Dordrecht: Springer.

Flaxman, S. M., and C. A. deRoos. 2006. Different modes of resource variation provide a critical test of ideal free distribution models. Behavioral Ecology and Sociobiology 61:877-886.

Fretwell, S. D., and J. H. J. Lucas. 1969. On territorial behavior and other factors influencing habitat distribution in birds. Acta Biotheoretica 19:1636.

Galvin, K. A. 2009. Transitions: pastoralists living with change. Annual Review of Anthropology 38:185-198.

Hamilton, I. M. 2010a. Foraging theory. In Evolutionary behavioral ecology. D. Westneat and C. Fox, eds. Pp. 177-193. Oxford: Oxford University Press. . 2010b. Habitat selection. In Encyclopedia of animal behavior. M. D. Breed and J. Moore, eds. Pp. 38-43. Oxford: Academic Press.

Hardin, G. 1968. The tragedy of the commons. Science 162:1243-1248.

Homewood, K. 2008. Ecology of African pastoralist societies. Oxford: James Currey.

Kennedy, M., and R. D. Gray. 1993. Can ecological theory predict the distribution of foraging animals? A critical analysis of experiments on the ideal free distribution. Oikos 68:158-166.

Kennett, D. J., A. Anderson, and B. Winterhalder. 2006. The ideal free distribution, food production, and the colonization of Oceania. In Behavioral ecology and the transition to agriculture. D. J. Kennett and B. Winterhalder, eds. Pp. 265-288. Berkeley: University of California Press.

Loth, P., ed. 2004. The return of the water. Gland, Switzerland: IUCN.

McCabe, J. T. 2004. Cattle bring us to our enemies: Turkana ecology, politics, and raiding in a disequilibrium system. Ann Arbor: University of Michigan Press.

McCay, B. J., and J. M. Acheson. 1987. The question of the commons: the culture and ecology of communal resources. Arizona Studies in Human Ecology. Tucson: University of Arizona Press.

Moritz, M., and P. Scholte. 2011. Ethical predicaments: advocating security for mobile pastoralists in weak states. Anthropology Today 27:12-17.

Moritz, M., P. Scholte, I. M. Hamilton, and S. Kari. 2013. Open access, open systems: pastoral management of common-pool resources in the Chad Basin. Human Ecology 41(3):351-365.

OPEN. 2009. Document de présentation des faits majeurs relatifs à l'insécurité dont ont été objet les communautés des pasteurs dans les plaines sèches et humides de la Région de l'Extrême Nord du Cameroun. Maroua, Cameroon: l'Observatoire du Pastoralisme dans la Province de l'Extrême Nord (OPEN).

Ostrom, E. 1990. Governing the commons: the evolution of institutions for collective action. Cambridge: Cambridge University Press.

Scholte, P. 2005. Floodplain rehabilitation and the future of conservation and development: adaptive management of success in Waza-Logone, Cameroon. $\mathrm{PhD}$ dissertation, Leiden University.

. 2007. Maximum flood depth characterises above-ground biomass in African shallowly flooded grasslands. Journal of Tropical Ecology 23:63-72.

Scholte, P., S. Kari, M. Moritz, and H. Prins. 2006. Pastoralist responses to floodplain rehabilitation in Northern Cameroon. Human Ecology 34:27-51.

Seignobos, C., and O. Iyébi-Mandjek, eds. 2000. Atlas de la Province ExtrêmeNord Cameroun. Paris: IRD \& MINREST.

Sutherland, W. J. 1996. From individual behaviour to population ecology. Oxford: Oxford University Press.

Sutherland, W. J., and C. W. Anderson. 1993. Predicting the distribution of individuals and the consequences of habitat loss: the role of prey depletion. Journal of Theoretical Biology 160:223-230. 
$\rightarrow$ Winterhalder, B., D. J. Kennett, M. N. Grote, and J. Bartruff. 2010. Ideal free settlement of California's Northern Channel Islands. Journal of Anthropological Archaeology 29:469-490.

Zborowski, I. D., ed. 1996. Atlas d'élevage du bassin du Lac Tchad. Montpellier, France: CIRAD-CTA. 


\section{Supplement A from Moritz et al., "Mobile Pastoralists in the Logone Floodplain Distribute Themselves in an Ideal Free Distribution" (Current Anthropology, vol. 55, no. 1, p. 115)}

\section{Applying the IFD Model in Complex Social-Ecological Systems}

We argue that the ideal free distribution (IFD) model, and, in particular, the depletion model, is a useful concept to understand the distribution of pastoralists in the Logone floodplain. The social-ecological system does, however, not fit several of the other assumptions of ideal free models. This poses a number of challenges in the operationalization of the theoretical model so that the IFD can be used to study the distribution of mobile pastoralists in the Logone floodplain.

First, cattle are organized in herds, so that movement decisions of individual cattle are not independent of those of other cattle. However, since we are studying the social-ecological system at a relatively large scale—on average, 343 herds and 17 habitats with large amounts of grazing resources-it is not problematic that decisions about movements are made at the level of the herd (rather than individual animals).

Second, pastoralists have no perfect knowledge about the suitability of all the patches. We argue that pastoralists have complete information, that is, sufficient knowledge to predict with a certain probability the patch conditions, instead of perfect information, that is, knowing the exact patch conditions (Kelly 1995). Cressman and Krivan (2006) and Cantrell, Cosner, and Lou (2008) modeled the evolutionary stability of movement rules that lead to ideal free distributions. These models predict that rules that achieve the IFD can yield higher payoffs than alternative rules, even when individuals only have information about their current patch and one other patch. Thus, even under limited information, ideal free habitat use may result.

Third, there are no distinct identifiable patches or habitats. Instead, habitats are defined by distribution of pastoralists in camp zones, which may overlap (see also Arditi and Dacorogna 1988). Cantrell, Cosner, and Lou (2008) modeled habitat selection along a gradient of habitat suitability, rather than discrete patches. They found that movement rules using local information could approximate the IFD.

Fourth, herds are not entering the floodplain and making a habitat selection one at a time. Instead, all mobile pastoralists enter the floodplain en masse when the floods recede. This makes it difficult to assess the suitability of the different habitats (because the cattle densities of the habitats are unknown), were it not that pastoralists usually go to their habitual camp zones, which allows pastoralists to make predictions about the expected distribution of other pastoralists and thus the suitability of the different habitats.

Fifth, even though forage and water are the most important factors in settlement decisions, other factors also affect settlement decisions. In other words, habitat quality is also shaped by nonforage constraints like access to markets and insecurity (Behnke et al. 2011; Winterhalder and Kennett 2006). This makes it difficult to assess suitability of habitats in complex social-ecological systems. Access to water and foraging resources is obviously important, but it is less clear whether and how nonforage factors should be weighed.

Sixth, one of the assumptions in behavioral ecology is that individuals make strategic decisions that optimize their fitness, and model outcomes are measured in terms of individual fitness. However, measuring fitness, or proxies like caloric returns, is difficult in this pastoral system. We tried using the cattle condition scoring technique (Nicholson and Butterworth 1986), but that turned out to be unfeasible. Instead, we use the concept of the IFD to measure the impact of mobile pastoralists on the environment with the assumption that if grazing pressure is proportionally distributed over the available resources, it is evidence of management of open access.

Seventh, travel times between habitats are non-negligible. It may take herds 2 or more days to get from one end of the floodplain to another. Moreover, during these movements animals expend energy and have less time to graze (which they make partially make up by grazing longer at night during movement days).

Eighth, pastoralists do not have similar preferences and assessment of habitats; their annual transhumance shapes and is shaped by habitual preferences for habitats on these orbits. The IFD model assumes that all individuals have the same preferences and assessment of habitats. That is clearly not the case in the Logone floodplain, where pastoralists show preference for specific camp zones.

Ninth, the distribution of pastoralists in the floodplain may be affected by Allee's principle, which explains that a patch's suitability initially is low when population densities are low and increases due to increasing population densities 
(Allee et al. 1949; Sutherland 1996). Allee's principle may play a role in the floodplain, as the perceived suitability of a camp zone increases initially when there are more (not fewer) pastoralists because pastoralists who camp alone or with only a few households are at higher risk of cattle theft.

The challenges notwithstanding, we think that the IFD is an appropriate model to describe and explain habitat selection of mobile pastoralists in the hot dry season in the Logone floodplain. We also argue that the IFD is an indicator of a selforganizing system of management of common-pool grazing resources in the Logone floodplain.

\section{Results}

\section{Normalized Difference Vegetation Index in the Study Area}

Pastoral mobility is driven by seasonal variations in rainfall, which results in spatiotemporal variation in pastoral resources: forage and water. FulBe pastoralists in the Far North region talk about four distinct seasons when they discuss their mobility patterns. The rainy season (duumol) runs from July through September with the biggest rains in July and August. It is followed by the cold dry season, (daBBunde) from October to January and the hot dry season (ceedu) from February to May. June is a transition season (seeto) from dry to rainy season. The change of seasons varies from year to year; that is, the hot dry season does not always start in February-sometimes it starts in March.

The change in normalized difference vegetation index (NDVI) values in the floodplain from a high of 0.7 to a low of 0.2 is a good reflection of the seasons described above (see fig. A1). NDVI values reach the highest point in the beginning of August (0.7-0.8 after the period of the big rains called loddo), then values start to decline, only to increase slightly again in September due to the flooding. Then at the beginning of October (at the beginning of the cold dry season) the values decline, and they reach the lowest value in April (0.2 in the middle of the hot dry season) and again start to increase at the end of May or beginning of June (depending on the start of the rains).
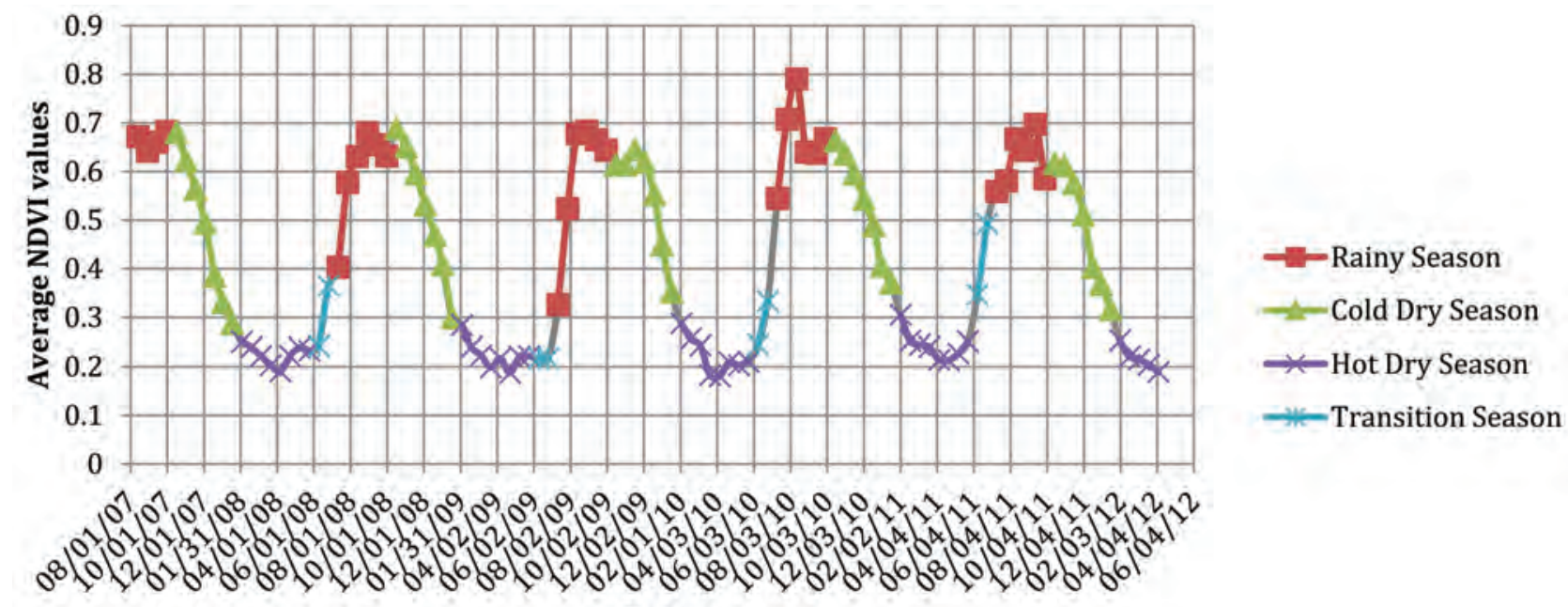

Dates

Figure A1. Average NDVI values in the study area, 2008-2012. The rainy season runs from July through September with the biggest rains in July and August. It is followed by the cold dry season from October to January and the hot dry season from March to May. June is a transition season from dry to rainy season.

The changes in NDVI capture well the general seasonal and flooding dynamics described for the Logone floodplain (Delclaux et al. 2010; Jung et al. 2011; Scholte 2005) that drive the movements of mobile pastoralists. Pastoralists leave the rainy season grazing areas (ruumirde) in the beginning of October and enter the floodplain by November, where they settle in their dry season campsites (ceedirde) by January or February and leave by May or June following the rain clouds.

\section{Change and Continuity in Pastoral Populations}

There is some continuation in occupation of the different camp zones over the years, but the changes from year to year in who occupies what camp zone are considerable (see tables A1 and A2). In the 5 years we documented the distribution of 
mobile pastoralists in the study area in February, we recorded 131 unique camp leaders. Only 35 of these camps (or camp leaders) had their ceedirde in the study area 3 or more years, while 96 were in the study area in February for only 1 or 2 years (see table A1). Moreover, in the 5 years pastoralists stayed in 35 unique camp zones in the study area in February. Only 16 of these camp zones were occupied for 3 years or more, while 19 camp zones were occupied for only 1 or 2 years in February (see table A2). Thus, the pastoral population and the camp zones that they occupied changed considerably from year to year. However, our results show that this had no major effect on matching of resources with animal numbers.

Table A1. Continuation in occupation-camp leaders, 2008-2012

\begin{tabular}{lccc}
\hline Years in the study area & Number of camps & Same zone in all years & $\begin{array}{c}\text { Same zone } \\
\text { in most of years }\end{array}$ \\
\hline 5 & 10 & 3 & 8 \\
4 & 12 & 3 & 11 \\
3 & 13 & 7 & 10 \\
2 & 26 & 10 & 10 \\
1 & 70 & NA & NA \\
\cline { 2 - 3 } Total & 131 & 21 & 39 \\
\hline
\end{tabular}

Note. NA $=$ not applicable.

Table A2. Continuation in occupation-camp zones, 2008-2012

\begin{tabular}{lccc}
\hline Years occupied & Number of camp zones & $\begin{array}{c}\text { Total number of camps } \\
\text { over 5 years }\end{array}$ & $\begin{array}{c}\text { Average number of } \\
\text { camps per year }\end{array}$ \\
\hline 5 & 7 & 121 & 3.5 \\
4 & 5 & 58 & 2.9 \\
3 & 4 & 34 & 2.8 \\
2 & 4 & 14 & 1.8 \\
1 & 15 & 33 & 2.2 \\
\cline { 2 - 3 } Total & 35 & 260 & \\
\hline
\end{tabular}

\section{NDVI in Established Camp Zones}

Most camp zones are well established and have been used for decades and are occupied every year by multiple camps, whereas others were occupied only once or twice during our study. We found that those areas that were occupied year after year have, on average, higher NDVI values than the areas that were never occupied and those areas that were occupied only once or twice during our study (see fig. A2). One-way Analysis of Variance (ANOVA) comparing the number of years that an area was occupied shows that there are statistically significant differences between the cells that were occupied for longer periods of time $(P<.0001)$. Thus, the camp zones that are most frequently used represent habitats that have over the years consistently higher NDVI values, that is, more grazing resources.

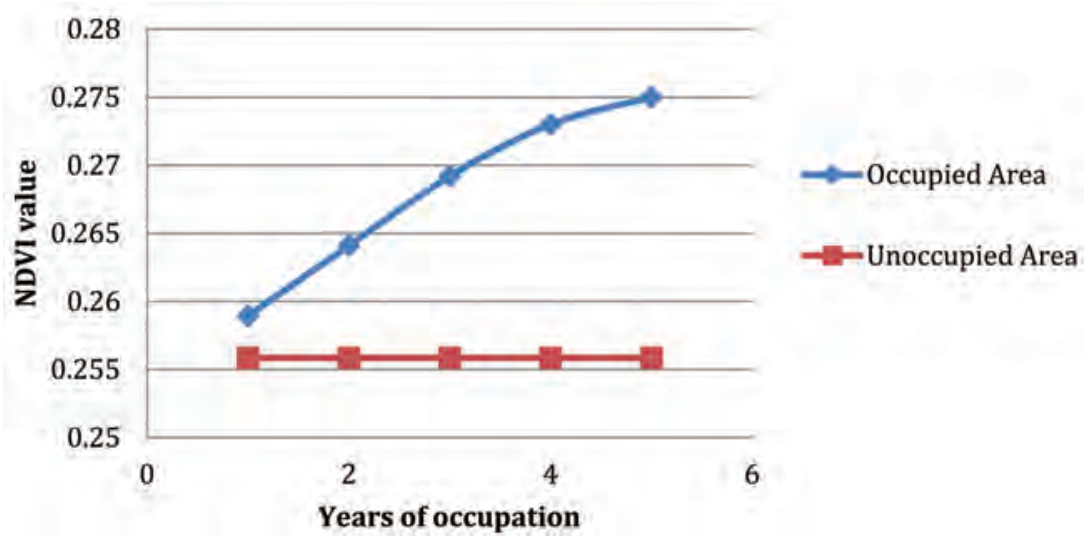

Figure A2. Average NDVI value and years of occupation of camp zones. 


\section{Spatial Distributions of Mobile Pastoralists and NDVI}

We examined whether there was evidence for an ideal free distribution in the Logone floodplain by testing whether there was a positive correlation between the total NDVI and the total number of animals per camp zone for the 5 different years. We also examined whether there were any patterns in overuse and under use, that is, whether the percentage of NDVI per camp zone buffer (as a percentage of the NDVI of all the camp zone buffers) was equal to the percentage of animals per camp zone buffer (as a percentage of the animals in all the camp zone buffers) in each of the years. If the percentage of animals was higher than the percentage of NDVI, it is considered a case of overuse (more animals than resources). If the percentage of animals was lower that the percentage of NDVI, it is considered under use (fewer animals than resources). We found that the number of camp zones that were overused stayed more or less the same across the years, although it was not always the same camp zones that were overused (see figs. A4-A8 and their legend, fig. A3).

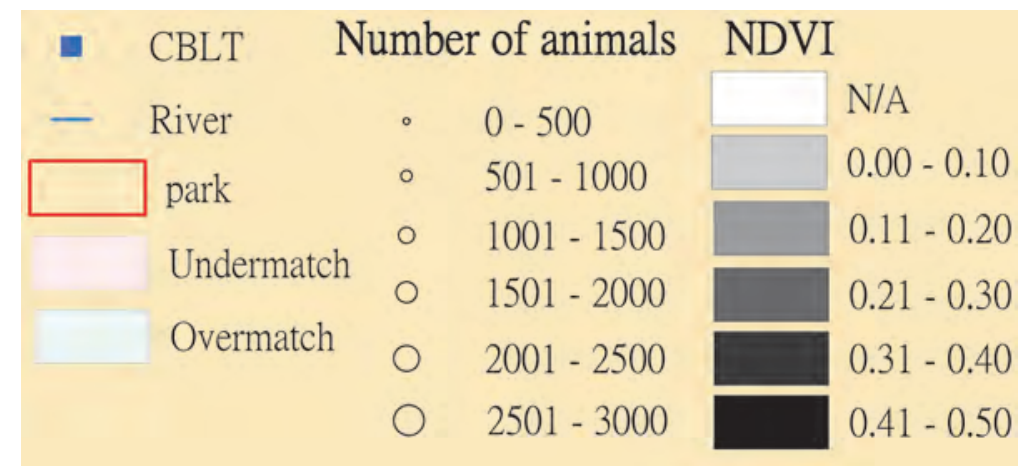

Figure A3. Legend for figs. A4-A8. 


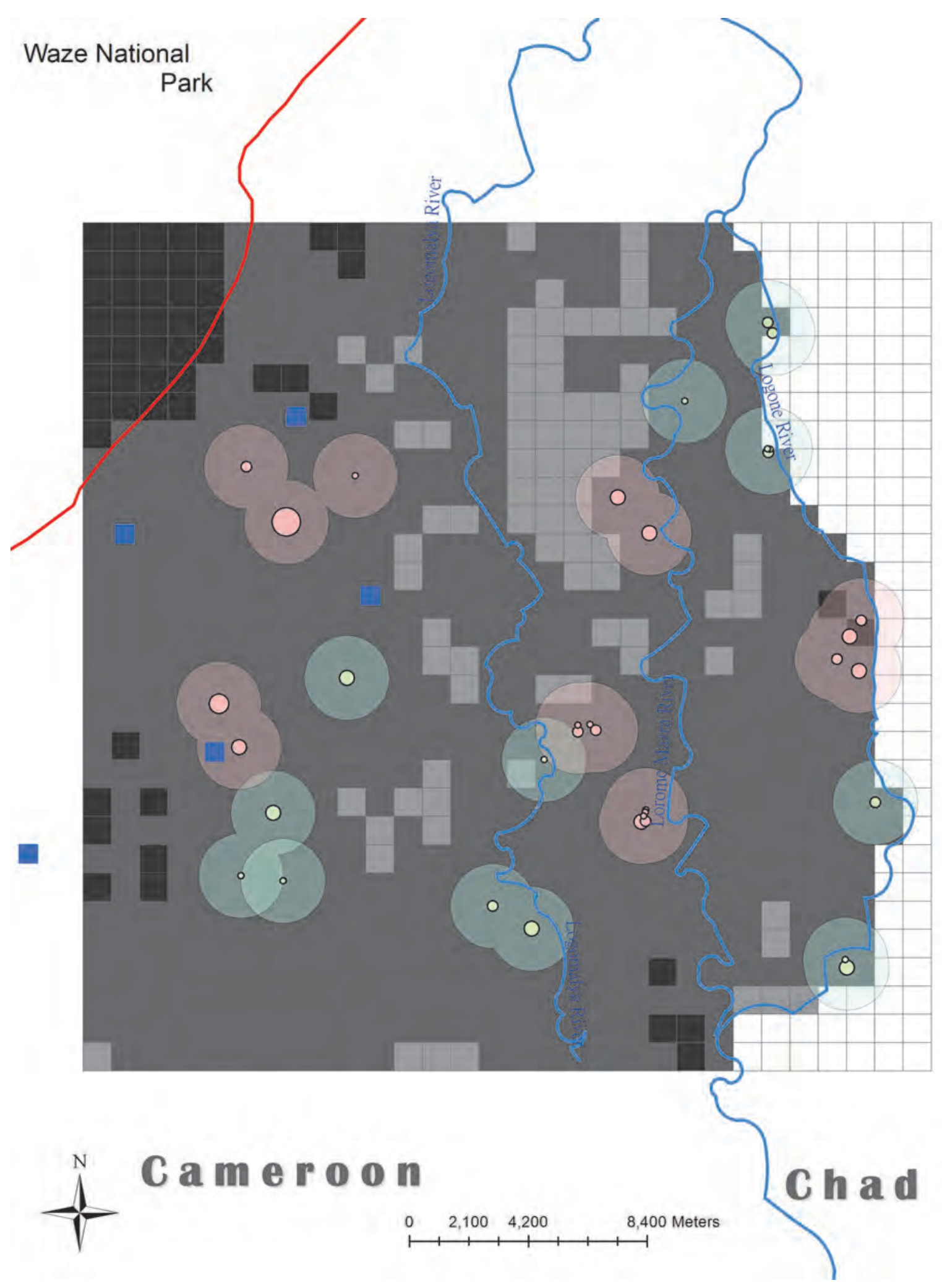

Figure A4. Distribution of mobile pastoralists in the study area in February 2008. For legend, see fig. A3. 


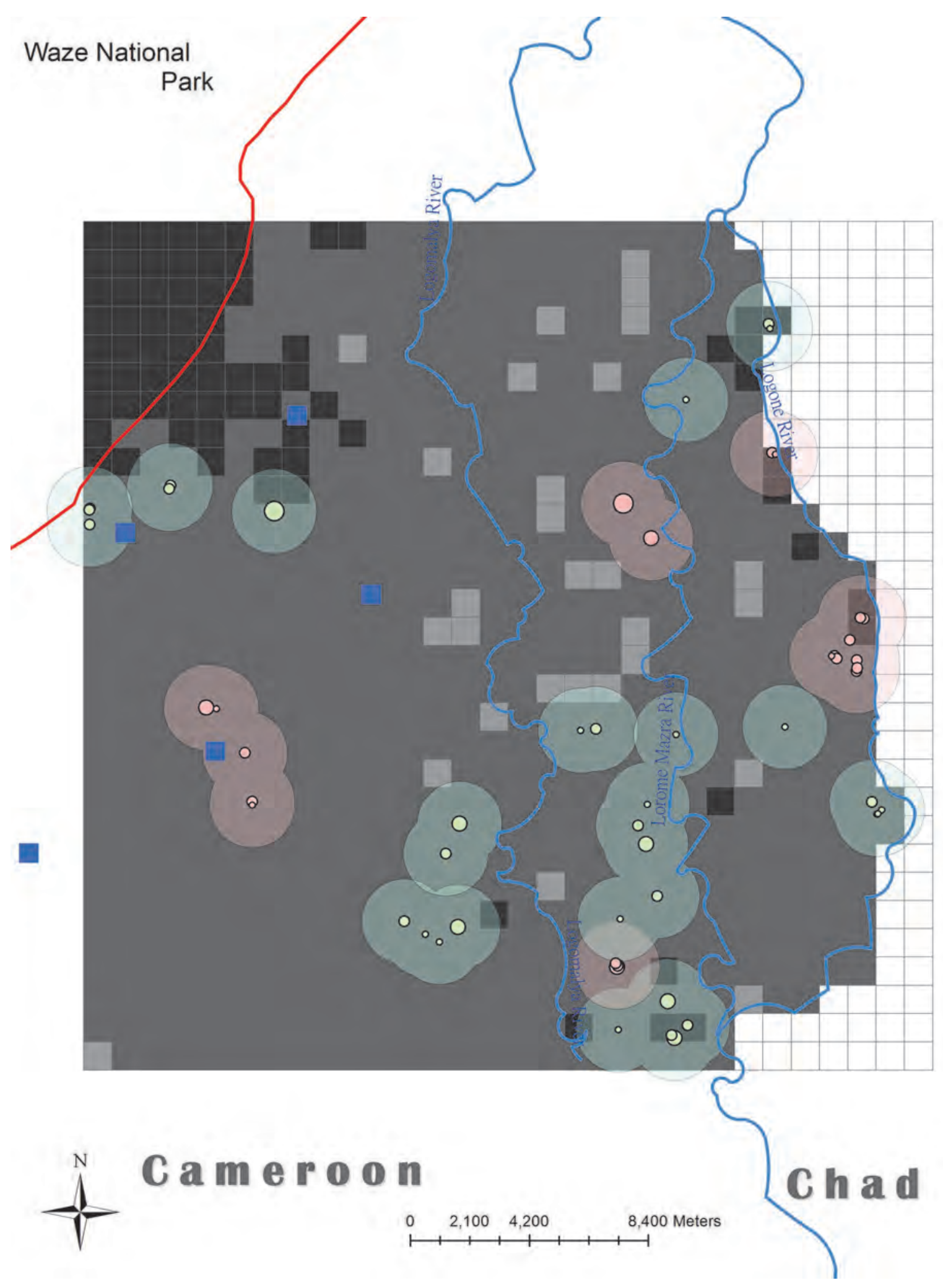

Figure A5. Distribution of mobile pastoralists in the study area in February 2009. For legend, see fig. A3. 


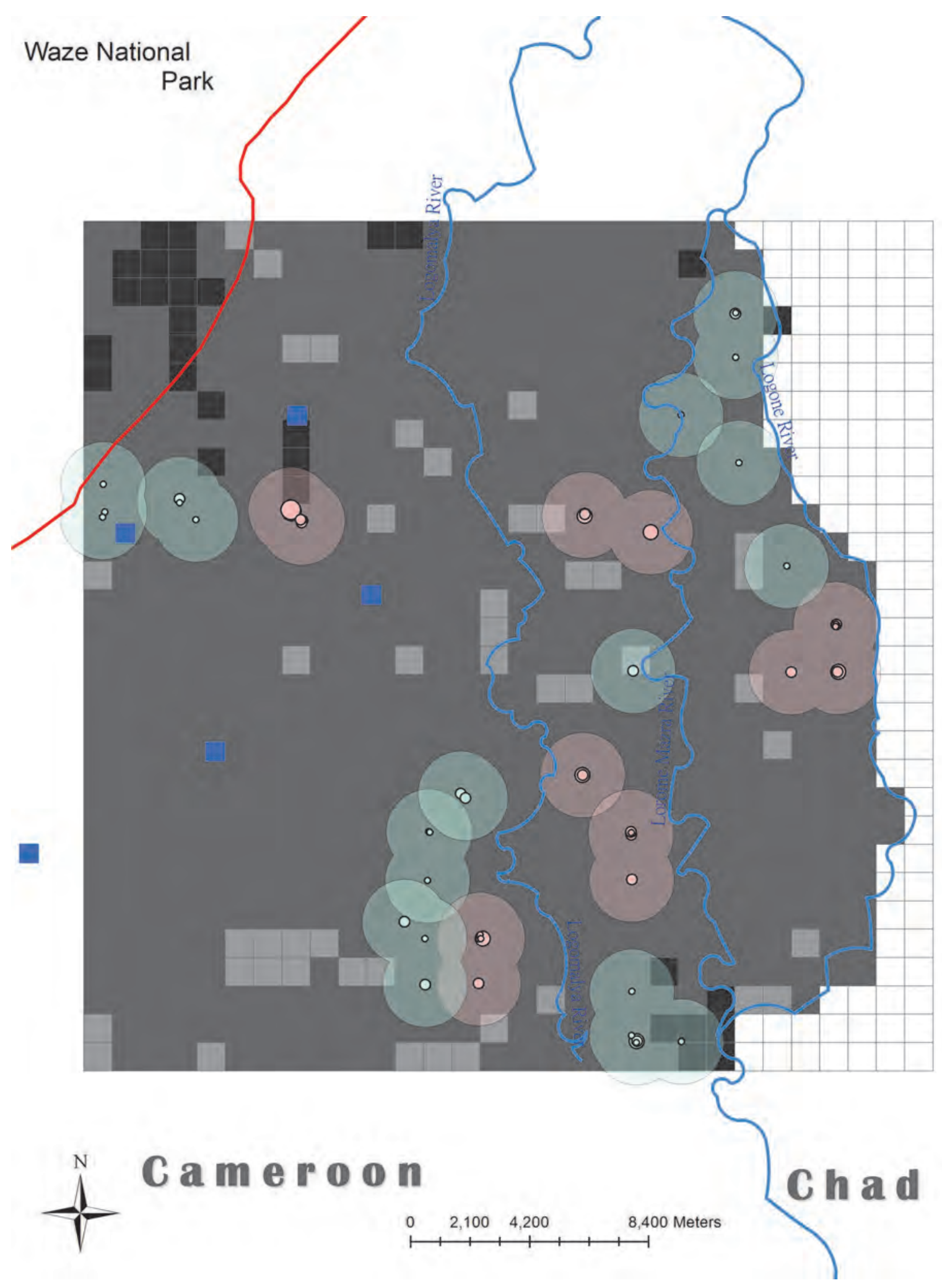

Figure A6. Distribution of mobile pastoralists in the study area in February 2010. For legend, see fig. A3. 


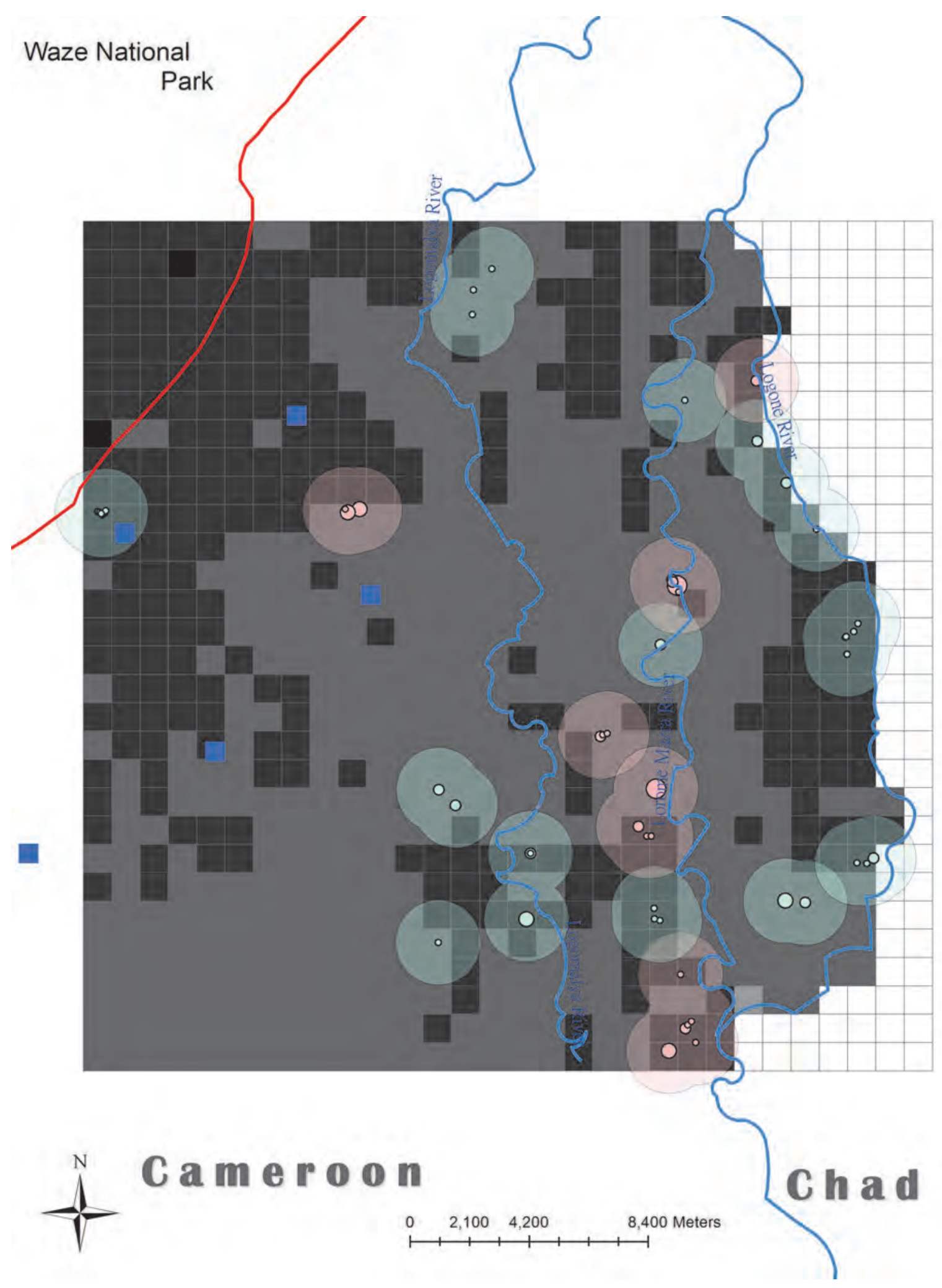

Figure A7. Distribution of mobile pastoralists in the study area in February 2011. For legend, see fig. A3. 


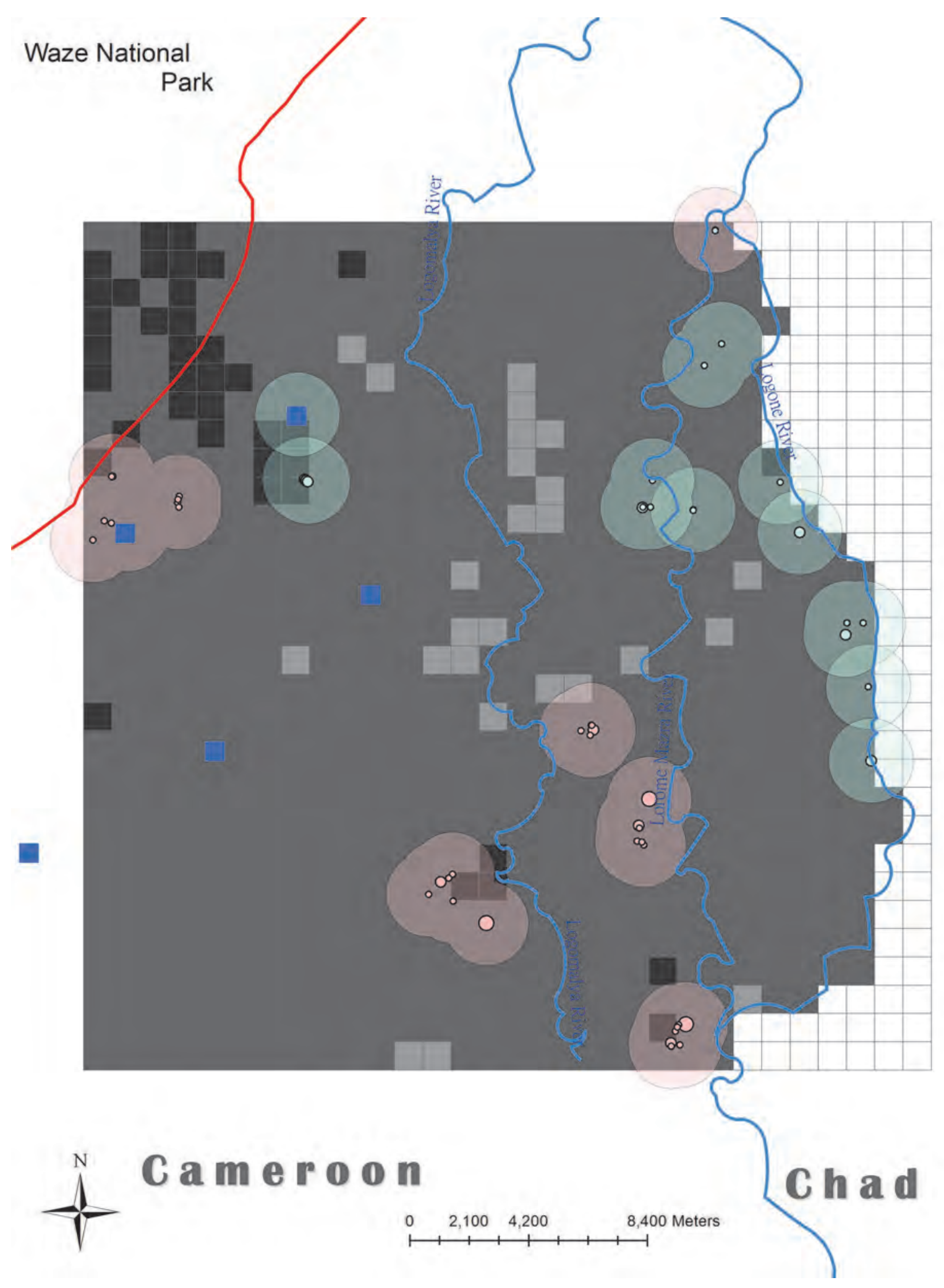

Figure A8. Distribution of mobile pastoralists in the study area in February 2012. For legend, see fig. A3. 


\section{References Cited Only in Supplement A}

Allee, W. C., A. E. Emerson, O. Park, T. Park, and K. P. Schmidt. 1949. Principles of animal ecology. Philadelphia: Saunders.

Arditi, R., and B. Dacorogna. 1988. Optimal foraging on arbitrary food distributions and the definition of habitat patches. American Naturalist 131:837-846.

Cantrell, R. S., C. Cosner, and Y. Lou. 2008. Approximating the ideal free distribution via reaction-diffusion-advection equations. Journal of Differential Equations 245:3687-3703.

Cressman, R., and V. Krivan. 2006. Migration dynamics for the ideal free distribution. American Naturalist 168:384-397.

Delclaux, F., C. Seignobos, G. Liénou, and P. Genthon. 2010. Water and people in the Yaéré floodplain (North Cameroon). In Floodplains: physical geography, ecology and societal interactions. M. A. Álvarez, ed. Pp. 1-27. Hauppauge, NY: Nova.

Jung, H. C., D. Alsdorf, M. Moritz, H. Lee, and S. Vassolo. 2011. Analysis of the relationship between flooding area and water height in the Logone floodplain. Physics and Chemistry of the Earth 36:232-240.

Kelly, R. L. 1995. The foraging spectrum: diversity in hunter-gatherer lifeways. Washington, DC: Smithsonian Institution Press.

Nicholson, M. J., and M. H. Butterworth. 1986. A guide to condition scoring of Zebu cattle. Addis Ababa, Ethiopia: International Livestock Centre for Africa.

Winterhalder, B., and D. J. Kennett. 2006. Behavioral ecology and the transition from hunting and gathering to agriculture. In Behavioral ecology and the transition to agriculture. D. J. Kennett and B. Winterhalder, eds. Pp. 1-21. Berkeley: University of California Press. 